\title{
Analysis of the Nexus between Trade Liberalization and Economic Growth: A Panel Study Of Brics Countries
}

\author{
Nana Asimeng Peasah (MBA) \\ Bahadur Institute of Management studies, Mysore University, Karnataka, India \\ E-mail: nanaassimengpeasah@gmail.com
}

Barnes Evans John (MA) (Corresponding author)

Department of Economics, Mysore University, Karnataka state, Mysore, India

Tel: 233-205-812-035Ｅ-mail: ebbarnes4@gmail.com

Received: October 31, 2016 Accepted: December 28, 2016

doi:10.5296/ber.v6i2.10235 URL: http://dx.doi.org/10.5296/ber.v6i2.10235

\begin{abstract}
BRICS countries forms a heterogeneous alliance. Their economic and political influence differ. They are distinguished by the outstanding size of their economies; strong growth rates and demand for stronger voice in the international governance and world economies. It is evident that BRICS have opened up their economies more than any other emerging economies. What is not clear to observers, is the extent to which international trade has contributed to the economies of these countries. The study therefore, seek to analyze the causal relationship between trade liberalization and economic growth among BRICS Economies
\end{abstract}

The study used a balanced panel data of the five BRICS Countries, (Brazil. Russia federation, India china and South Africa). For a period spanning from 1990 to 2014.

Using a static fixed effect model and a dynamic panel of the Arrelano-Bond approach to GMM we estimate the dynamic impact of trade liberalization on Economic Growth, we found that under both the static and dynamic model, trade liberalization (proxy by TO) was found to exert positive and significant impact on economic growth rate.

It is suggested that developing countries that want to follow the path of BRICS economies to economic recognition should consider developing internal institutions that leads to a greater trade openness (liberalization). 
Keywords: BRICS, Panel data, Trade liberalization, Economic Growth, Trade openness

\section{Introduction}

The growth of BRICS countries particularly china and India over the last two and half decade has been phenomenal. Even in the face of global economic difficulties and various forms of recessions, BRICS economies have done extremely well during the last decades, achieving remarkable growth rates over the years 1990-2010 and is projected that these countries will emerge as world economic superpowers by 2050.

These performances have generated a lot of interest as well as debates among researchers, academicians and policy makers of the possible factors that might have engineered such performances. Most of the economic literature considers that trade liberalization leads to an increase in welfare derived from an improved allocation of domestic resources. Import restrictions of any kind create an anti-export bias by raising the price of importable goods relative to exportable goods. The removal of this bias through trade liberalization will encourage a shift of resources from the production of import substitutes to the production of export-oriented goods. This, in turn, will generate growth in the short to medium term as the country adjusts to a new allocation of resources more in keeping with its comparative advantage (McCulloch, winters and Cierra, 2001). This process is neither smooth nor automatic. On the contrary, it is expected to create adjustment costs, encompassing a wide variety of potentially disadvantageous short-term outcomes. These outcomes may include a reduction in employment and output, the loss of industry- and firm-specific human capital, and macroeconomic instability arising from balance-of-payments difficulties or reductions in government revenue (Matusz and Tarr, 1999). The size of the adjustment costs depends on the speed with which resources make the transition from one sector to another.

However, trade liberalization in and of itself has not yet been unambiguously and universally Linked to subsequent economic growth. Despite the vast literature looking at this link, numerous empirical studies have not found the evidence conclusive. Rodriguez and Rodrik (1999) argue that the literature is largely uninformative, and that there is a significant gap between the conclusions derived from theory and the facts. According to the authors, a number of factors explain this gap. In many cases, the indicators of openness used by researchers are problematic, as measures of trade barriers are highly correlated with other sources of poor economic performance. In other cases, the empirical strategies used to ascertain the link between trade policy and growth has serious shortcomings, the removal of which results in significantly weaker findings. Moreover, the simultaneous implementation of other far-reaching reforms makes it difficult to disentangle the impact of the trade liberalization process. This being said, it is also important to note that although trade openness has not been unequivocally linked to higher growth, it has certainly not been identified as a hindrance.

Attempts to access the economic impact of trade policy openness on growth go back several decades, but until the early 1990s it simply involved comparisons of GDP growth between opened and closed countries, or before and after trade liberalization. Classic examples of the pure before and after approach are two publications by the World Bank (Nash and Thomas, 
1991; and Papageorgiou et al 1991) that identified a year of liberalization and after observing higher GDP growth after the reforms, concluded that trade liberalization indeed leads to higher growth. The major caveat under this approach is that it does not properly study or control for other factors that could have boosted growth after trade liberalization. For instance, it did not account for the Fact that many countries liberalized trade and at the same time exited a communist regime, ended a political conflict, or rebounded from a short-term recession

Readings of the existing evidence demonstrate the Inconclusiveness and highly ideological nature of the debate. Thus the question of what happened to countries after their trade reforms continues to be an important issue in the policy discussions of many developing countries. A key issue about this debate is that, almost all developing countries have liberalized their trade regimes over the

Last few decades (IEG, 2006). Thus, the issue of what happened to these countries is of interest beyond the question of whether or not all the changes can be attributed solely to the trade.

\subsection{Research Problem}

It is evident that BRICS economies have been practicing export-led growth strategies over the recent decades and have opened up their economies more than any other emerging economies. What is not clear to observers, is the extent to which international trade has contributed to the economies of these countries.

From Adams Smith theory of absolute advantage, it is found that international trade leads to efficient resource allocation enabling countries to achieve higher level of income and standard of living. An explicit elucidation of the impact of trade on economic growth is provided by new growth theories by Romer (1986) and Lucas (1988). In essence, trade promotes growth via various channels.

Trade liberalization- the removal of restrictions or barriers to the free flow of exchangeable goods between countries and also the removal of both quantitative and non-quantitative restriction in theory have been accessed to have positive impact on economic growth. It is evident that, all countries that have sustained economic growth have opened up their markets to trade and Investments. By liberalizing trade and capitalizing on comparative advantage have benefited economically. It leads to efficient and improved allocation of domestic and world resource. It also improves welfare by making more goods available to consumers at a competitive price.

Reallocation of productive resource from the production of import -substitute goods to export -lead comparative advantage goods accelerate growth from the short to medium term.it also lead to introduction of new technologies. a liberalized trade regime may increase world output as whole but evidence from country-specific or cross countries studies has since not been conclusive.

Opponents argue that, Transition from protective trade regime to liberalized trade regime is 
not automatic- it is expected to create adjustment cost, and potentially dangerous outcome in the form of employment and output loss. In some cases some domestic industries that are not able to keep up with the competition have loss major part of their market share or has had to close down. Unstable macroeconomic problem arising from balance of payment problems, exchange rate misalignment is but few of the negative outcomes of liberal trade policies.

Hence the net impact of trade liberalization on Economic Growth has not been conclusive. Although earlier studies point to a positive link between international trade and economic growth, the said studies are flawed in some respects. For instance, the growth effects of international trade are deemed to be static (Martínez and Ramos, 2005), albeit recent studies point to dynamic effects of international trade (Baldwin, 1992). Again the methodological approach and appropriate proxy has not been properly established. Moreover, despite the fact that the impact of international trade on economic growth has been a widely research area, studies conducted for the BRICS are scarce

The current study therefore fills the gap in the literature by analyzing the nexus between trade liberization and economic growth in the BRICS economies by using the dynamic generalizes method of moment (GMM) approach to panel estimation. Table 1. The capitals, assets and revenue in listed banks

\section{Empirical Review of Trade and Growth Nexus}

Like its theories, similar number of empirical literature exist on the relationship between economic growth and trade liberalization. However, evidence of the impact of trade liberalization on economic growth are far from unanimity.

Despite the many literatures on trade and growth Nexus our checks noted that, Empirical studies regarding the link between trade and economic growth in the BRICS economies are rather scant. Notwithstanding this drawback there have been some studies conducted to investigate the contribution of international trade to growth individually in these economies. For example, empirical studies regarding China are done by Kwan and Andy (1991), Kwan and Kwok (1995), Tong (1995), Li (1996), Fan et al (2005) among others. Studies for Brazil are very scarce and are done by Matos (2003) and Domal and Ozyurt (2010) among others. As far as Russia is concerned, studies are scarcer and was done by Ledyaeva and Linden (2008). Kwan and Cotsomitis (1991), Kwan and Kwok (1995) study the link between trade and growth in China and find that output is exogenous and there is a unidirectional causality between trade and growth.

Tong (1995) examines the link between import and economic growth and found a positive one although import contributed differently to growth overtime.

Shen (1999) examine the export-led growth of China and find bi-directional causality between export and growth, albeit no long term link between the variables. Li (1996) assesses the link between exports and economic growth for China and concludes that exports contributed enormously to growth. Recently, Fan et al (2005) investigate the link between exports and growth in China using data from 1952 to 2003 and concludes export growth leads to economic growth. As far as Brazil is concerned, Chow (1987) examine the export led 
growth hypothesis for Brazil among industrialized countries using data for the period 1960-1987 and find a bidirectional causality between exports and growth in Brazil. Similarly, Matos (2003) employed data for the period spanning 1980-2002 to examine the link between exports and economic growth and finds bi directional causality between exports and economic growth. Domal and Ozyurt (2010) examine the determinant of economic growth for 26 Brazilian states for the period 1989-2002. The authors conclude that trade openness as well as human capital formation contributed enormously to growth during the period considered. Ledyava and Linden (2008) provide some evidence for Russia. They examine the factors influencing growth in 74 Russian states for the period 1996-2005 using both panel and cross sectional data analysis and find that apart from investments, economic development, exports is high significant in explaining growth in Russia. Studies including India are conducted by Dutt and Ghosh (1996), Anwer and Sampath (2001), Nidugala (2001), Bhattacharya and Bhattacharya (2011) among others. Their studies find a unidirectional causality from exports to economic growth. Last, but not least, as far as South Africa is concerned, empirical studies are provided by Loots (2002) and Kowalski et al (2009). Loots (2002) employed quarterly data for the period 1990-2000 to investigate the impact of trade liberalization among others and find that only 50\% explains growth during the period considered and that growth in South Africa emanates from growth in Latin America and other emerging countries. Kowalski et al (2009) examined among others the impact of trade liberalization on economic growth in South Africa during data for the period 1988-2003 and found a positive impact of trade liberalization on growth.

\subsection{Overview of BRICS}

The term BRICS is the acronym for an association of five major emerging national economies: Brazil, Russia, India, China and South Africa. During its inception, the association was originally known as "BRIC" before South Africa was included in the year 2010. The BRICS countries, all being members of the G-20 are developing or newly industrialized countries, but they are distinguished by their large, fast-growing economies and significant influence on regional and global affairs. Since 2010, the BRICS nations have met annually at formal summits. Russia currently holds the chair of the BRICS group, and will host the group's seventh summit in July 2015.

The five BRICS countries represent almost 3 billion people as of 2014, or $40 \%$ of the world population approximately. The combined nominal GDP of the five nations is US\$16.039 trillion, equivalent to approximately $20 \%$ of the gross world product, and an estimated US\$4 trillion in combined foreign reserves. The BRICS have received both praise and criticism from numerous commentators.

Mr. Jim O'Neill the then chairman of Goldman Sachs Asset Management coined the term BRIC in 2001, in his publication Building Better Global Economic BRICs. In September 2006, the foreign ministers of the initial four BRIC states (Brazil, Russia, India, and China) met in New York City, beginning a series of high-level meetings. A full-scale diplomatic meeting was held in Yekaterinburg, Russia, on 16 June 2009. 


\subsubsection{Brics and Trade}

BRICS countries do not form a homogeneous alliance. Their economic and political influence differ. They are distinguished by the outstanding size of their economies; strong growth rates and demand for stronger voice in the international governance and world economies. Among the BRICS countries, South Africa seems to be at the lower end of the ladder in terms of economic and political influence. China is tipped to be the next superpower while Russia boast of being a formal superpower. This heterogeneity among BRICS seems to make a general analysis of the group complicated.

The growth in Trade among the BRICS-Group over the last decade has been remarkable. The growth rate of exports was $13.3 \%$ in the mid 1990ies and $49.8 \%$ ten years later, growth of imports was $13.2 \%$ and $47.7 \%$, respectively. With these remarkable growth rates, large parts of the GDP growth of these countries were induced by trade. The export share of GDP was $9.2 \%$ in 1980 and $26.6 \%$ in 2009, while the import share increased from $11.3 \%$ to $20.4 \%$ in the same period (Orgaz et al. 2011: 22). Bilateral Trade is considered to be the backbone of LIC-BRIC relations (IMF 2011a: 6). LIC export to BRIC grew from USD 15 billion in 2000 to USD 61 billion in 2009, Pushing back the EU and the USA to receive less than $45 \%$ of LIC exports. Among all BRICS, China and India are the main consumers of LIC exports, followed by Brazil. In 2010, China and India account for more than $90 \%$ of LIC exports of agricultural raw materials and for almost $85 \%$ of fuels exports to BRICS. $52 \%$ of exports of manufactured goods went to China, followed by Brazil (14\%), Russia, India and South Africa (10\% each) (UNCTADstat). Crops, minerals and other raw materials, especially fuels and metals, are the main component of LIC export to BRICS. One reason for the increase in LIC-BRIC trade figures are complementary trade structures providing overlap between BRIC demand and LIC supply (IMF 2011a: 13 f). With regard to SSA, trade figures increased tremendously not only for the BRICS but also for the EU and the US, starting in 2002 (with a temporary downturn in mid-2008 due to the financial crisis). It should be noted, however, that BRICS' total merchandise trade with SSA in 2010 exceeded for the first time the one of the EU (cf. figure 3).

The demand for resources has been increasing in the past decade, among the BRICS mainly due to strong growth of Chinese and Indian manufacturing industries. These circumstances have led and might continue to lead to strong price increases of raw materials. This has consequences for LICs on both sides: Those LICs that are importers of (most) raw materials, including oil, pay a higher import bill, which is not compensated by higher prices of their export products. But even LICs that are exporting raw materials and are potential winners of the price boom, run the risk of increasing their dependency on raw material exports, which might compromise the formation of significant manufacturing industries. Moreover, currency appreciation due to increased export earnings can lead to undesired negative effects in traditional export industries as they lose In support of the SW indicator,Berg and Krueger (2003) opine that despite some technical deficiencies, the SW indicator is a fairly accurate indicator of trade restrictiveness. However, their assertion did not convince the skeptics about any evidence based on this indicator. 
Dollar and Kraay (2004) try to introduce a different approach to the measurement and try to measure the increase in trade openness (i.e. trade liberalization) by accounting for the changes in trade flows between any two periods of time. However, this indicator was promptly and convincingly criticized by Rodrik (2001) essentially for not recognizing the endogenous relation between trade flows and GDP growth.

Other papers trying to approximate trade policy openness through trade flows (Leamer,1998; Hiscox and Kastner, 2002; Bolaky and Freund, 2004) were subject to the same criticisms. Wacziarg and Welch (2003) on the other hand, avoid the difficulties involved in measuring

Trade restrictiveness by performing a fixed effects regression based on the prior identification of trade liberalization episodes. This methodology was originally applied in SW, and despite the more Sophisticated econometric technique involved, it is essentially an event study similar to those conducted until the early 1990s. Wacziarg and Welch do find an increase in GDP growth after trade liberalization. As the before and after studies of decades ago, WW assume that all the acceleration is attributable to trade liberalization despite the fact that several of the countries in their sample have simultaneously undergone enormous transformations and changes in the external environment. Their sample includes countries that have gone through the transition from socialism to the market economy, and countries that had conflicts and other non-economic upheavals. There are also countries that are dependent on one or two highly volatile products and have fluctuations that cannot easily be attributed to policy changes. In addition, defining years of reform based on the SW criteria leads to several misidentifications of liberalization episodes. These deficiencies are described in more detail in the following section, which proposes a correction of the before and after methodology as applied in SW and WW and previous event studies competitiveness on the world market (a common phenomenon known as the Dutch Disease.

\section{Methodology}

The previous chapter discusses the literature on the various theoretical and empirical works done on similar areas of research. This chapter outlines the methodology adopted for the study. It specifically includes the type of data used, specification of the model, explanation of the variables, and a prior expectation of the signs for the variables, stationarity tests, and method of estimation.

\subsection{Data Type and Source}

The study uses a balanced panel data spanning from 1990 to 2014. Data for the variables are sourced from World Bank development indicators (2014). International monetary fund International Financial Statistics and also from the central bank of respective countries. All the BRICS countries; Brazil. Russia, India, China and South Africa were included in the study. The main motivation for chosen is based on data availability for the principal variables. Other sources of supporting information include published articles, journals, working papers and textbooks. Variables used in the study were GDP per capita growth rate, trade openness, gross fixed capital formation, human capital formation, exchange rate. Data analysis software STATA 13 is employed to analysis the data. 


\subsubsection{Model Specification}

In order to analyze more precisely the links between opening up of the economies and economic growth, it is useful to carry out some econometric investigations. Economic growth depends on a variety of factors: standard economic theories consider capital accumulation a key driver, while more recent growth models emphasize the role of human capital. It should be noted that capital Stock formation depends on (private and public), fixed investment, which can be supported by a high saving rate (this is the case of China) but partly derives also from foreign investment. So, FDI and fixed capital stock formation are two not entirely independent variables; in addition, trade and FDI are also interrelated, since FDIs are, especially in China, export-oriented.

The empirical works on the growth effects of trade have followed a variety of approaches. Despite the numerous measures and variables, it is important to bear in mind the distinction between trade growth (for whatever reason, including reduction in transport and communication costs) and trade policy (liberalizations, reduction of tariffs.). The most recent studies followed either cross-section or panel approaches, usually with large samples of countries: see for example Edwards (1998), Frankel and Romer (1999), Makki and Somwaru (2004), Sarkar (2008). In some cases, cross-sections are based on sub-national data, e.g. China's provinces: see Sun and Parikh (2001), Jin etal. (2008); or on many sectoral data: see Milner et al. (2007).

Our is derived from the framework of the solow model. Other growth determinant variables identified through the review of literature are included to avoid model mis-specification

Following the works of Markiw and et al (1992) the model is specified as:

$$
\mathrm{Y}_{\mathrm{it}}=\alpha_{0}+\beta \mathrm{Y}_{\mathrm{it}-1}+\lambda \mathrm{to}_{\mathrm{it}}+\gamma \mathrm{Z}_{\mathrm{it}}+\theta_{\mathrm{i}}+\theta_{\mathrm{t}}+\varepsilon_{\mathrm{it}}
$$

Where the variable $Y_{i t}$ is growth rate of annual GDP for country $i$ at time t. $Y_{i t^{-1}}$ is the previous (lagged 1) value of annual GDP growth rate to account for the dynamic nature of the model.TO is trade openness which is used as a proxy for trade liberalization - the principal variable of interest in the model. Zit is a vector of other growth determinant variables. $\theta_{\mathrm{i}}$ is unobserved country specific effects and account for the heterogeneity across countries. $\theta \mathrm{t}$ is time specific effect and Eit is the stochastic error term. The following variables were included as determinant of growth. Net foreign direct investment (NFDI), human capital formation (HCF) gross domestic fixed capital formation (GDCF) and exchange rate

Equation one is rewritten in an expanded and logarithm form as

$$
\begin{aligned}
& \text { Yit }=\alpha_{0}+\alpha_{2} \text { LNTOit }+\alpha_{3} \text { LNNFDIit }+\alpha_{4} \text { LNHCFit }+\alpha_{5} \text { LNEXit }+\alpha_{6} \text { LNGCFit }+\alpha_{7} \ln p o p u_{\text {it }} \theta \text { i }+
\end{aligned}
$$

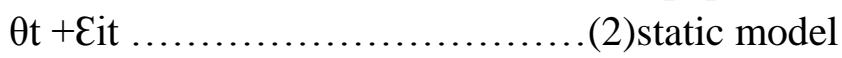

And in dynamic form as

$$
\begin{array}{r}
\text { Yit }=\alpha_{0}+\alpha_{1} \text { Yit-1 }+\alpha_{2} \text { LNTOit }+\alpha_{3} \text { LNNFDIit }+\alpha_{4} \text { LNHCFit }+\alpha_{5} \text { LNEXit }+\alpha_{6} \text { LNGCFit } \\
+\alpha_{7} \text { lnpopu }_{\text {it }} \theta \mathrm{i}+\theta \mathrm{t}+\varepsilon_{\text {Lit }} \ldots \ldots \ldots \ldots \ldots \ldots \text { (3)dynamic model }
\end{array}
$$

All variables are as explained above, Eit denotes the error term, $t$ time and $\ln$ natural 
logarithm. A $\alpha_{i}$ represent the elasticity coefficients. The variables; foreign direct investment, human capital formation, real effective exchange rate, and population size of the countries are express in logarithmic form. Hence the coefficients are interpreted as elasticities.

Table 1. Variables Measurements and Their Prior Expectation

\begin{tabular}{|l|l|l|}
\hline VARIABLE & MEASUREMENT & $\begin{array}{l}\text { Expected } \\
\text { SIGNS }\end{array}$ \\
\hline Economic growth (y) & Real GDP per capita & $\begin{array}{l}\text { Dependent } \\
\text { variable }\end{array}$ \\
\hline Economic growth (lagged one) & Previous year value real GDP per capita & $>0$ \\
\hline Trade openness (TO) & (Exports + Imports) Volume as a percentage of GDP & $>0$ \\
\hline Foreign direct investment (NFDI) & $\begin{array}{l}\text { Net inflows (new investment inflows less } \\
\text { disinvestment) }\end{array}$ & $>0$ \\
\hline Human capital formation(HCF) & Secondary school enrolment & $>0$ \\
\hline $\begin{array}{l}\text { Gross fixed capital formation } \\
\text { (investment)(GDCF) }\end{array}$ & $\begin{array}{l}\text { GDCF by government and private sector as a } \\
\text { percentage of GDP }\end{array}$ & $>0$ \\
\hline $\begin{array}{l}\text { Exchange rate (EX) } \\
\text { value of a currency against a weighted average of } \\
\text { several foreign currencies) }\end{array}$ & $>0$ \\
\hline
\end{tabular}

\section{Estimation Results and Discussion}

\subsection{Panel Estimation: Fixed Effect Model}

To estimate the relationship between growth and trade liberalization, we have make use of both static and time variant (dynamic) models. The static model looks at the current impact of the explanatory variables on our dependent variable. Given the fact economic/trade policy takes time before the impact is manifested, we estimate a dynamic panel using the Arrelano-Bond approach to GMM.

In the static model, both the fixed and random effects model is estimated. We analyzed the results of the fixed effects model based the decision arrived by using the Hauseman text of model selection. Consequently, the results of the fixed effect model are shown in table 4.3 and the random effects are shown in appendix 
Table 2. Results of Fixed Effect Model

\begin{tabular}{|c|c|c|c|c|}
\hline Variable & Coefficient & Std error & t-statistics & $P$ - value \\
\hline TO & 5.089259 & 1.649143 & 3.086002 & 0.0025 \\
\hline Lnfdi & 1.851955 & 0.306816 & 6.036053 & 0.0000 \\
\hline Lngfef & 1.709669 & 1.703281 & 1.003750 & 0.3176 \\
\hline Lnexrate & -1.728422 & 1.939865 & -0.891001 & 0.3748 \\
\hline Inpopulation & 12.00789 & 3.074326 & 3.905860 & 0.0002 \\
\hline Lnhcf & 17.96689 & 6.788383 & 2.646712 & 0.0093 \\
\hline $\begin{array}{ll}\text { Hausman } & \text { Test } \\
\text { Chi2 value } & 32.07 \\
\text { Prob>chi2 } & 0.000\end{array}$ & & & & \\
\hline R squared & 0.620041 & & & \\
\hline Adjusted R squared & 0.586712 & & & \\
\hline F statistics & 18.60327 & & & \\
\hline Prob(f-statistics) & 0.000000 & & & \\
\hline
\end{tabular}

Dependent variable: real GDP per capita growth rate

In selecting between the random effect and fixed effect model we used the Hausman test. The generally accepted way of choosing between fixed and random effects. The null hypothesis for the Hausman test is that the random effect is appropriate against the alternate hypothesis fixed effect is appropriate. The results of the test which is shown in table 2 shows that the fixed effects model best fit for our static model hence the results are taken for interpretation.

From table 2, adjusted $\mathrm{R}$ square which is preferred over $\mathrm{R}$ squared is 0.586712 . This means that about $58.6 \%$ of the variations in in annual GDP growth rate among BRICS countries is accounted for by changes in the explanatory variables used in the model. The combined impact given by the $\mathrm{F}$ statistics is statistically significant, implying that all the explanatory variables taken together significantly affects the growth rate of GDP. This results is good and speaks well of the model.

As already mentioned, the overriding objective of the study is to measure the economic growth impact of open trade policies among BRICS countries.

From table 2, the coefficient of trade openness (to) is positive and statistically significant. This means that open trade regime has significant impact on the growth rate of BRICS countries. Specifically, a 1 percent increase in the openness rate results in 5.08 units increase in GDP grow rate. This results is in tandem with findings of Chengxiang and Shen (1999) and Kowalski et al (2009). the implication is that, as BRICS countries open up their economy by removing trade barriers, (removal/reduction of tariff rate), abolition of other unfavorable trade policies etc while contributing to industrial efficiency and reduced cost to consumers (improved consumer welfare) translate to improving overall economic performance of the country. Thus this finding is in line with economic literature by export-led growth hypothesis (ELGH), pioneered by Feder (1982), of which, one of the main causes of growth is growth in exports. 


\section{MlMacrothink}

Business and Economic Research

ISSN 2162-4860

2016, Vol. 6, No. 2

The coefficient of foreign direct investment as expected is positive and statically significant at $1 \%$ level. Specifically, a one percent change, increase (decrease) in FDI will results in about $18 \%$ increase (decrease) in annual growth rate among BRICS. The market sizes of BRICS economies measured by GDP per capita coupled with the size of their populations have led to a worldwide increase in FDI inflows to BRICS countries. This is expected to further strengthen the growth rate of their economies. For example A new UN report in 2013 acknowledge that BRICS continued to be strong performers in attracting foreign direct investment, almost doubling their share from the pre-crisis level, BRICS now account for over one fifth of global FDI with China gaining the $2^{\text {nd }}$ spot, Russia $3^{\text {rd }}$ and Brazil $7^{\text {th }}$ in the list of top 20 host economies of 2013.BRICS countries are therefore expected to consolidate further gains from trade as their economic and demographic characteristics continue to act as a catalyst of attracting FDI.

The coefficient of gross capital formation though positive as expected was not significant for the study period. Likewise exchange rate was negative and insignificant in explaining the growth rate of annual GDP for the study period.

Amongst other factors, the population size of a country has a direct impact on the potential size of its economy. A large population capacity can function as an engine to a country's economic growth and development. One main distinguishing feature of BRICS is the size of their population all five members are in the top 25 of the world by population and their combined populations of 3 billion people as of 2014 which is $40 \%$ of the world. Here, the objective is to find out whether population size also contributes to their growth performance. As shown in table 2 the coefficients are positive and highly significant. This means that population size has been a dividend to BRICS countries. For every $1 \%$ increase in population size will results in about $12 \%$-point increase in annual GDP growth rate.

The final variable in our model is human capital formation. This is the stock of knowledge, habits, social and personality attributes, including creativity, embodied in the ability to perform labor so as to produce economic value. The coefficient of LNHCF is positive (17.96689) and statistically significant. Thus an increase in education and training which improves the human capital of a country contributes to higher economic growth.

\subsubsection{Dynamic Panel Estimates}

Given the fact that economic policies usually take time to have the desire impact, we went further to estimate the dynamic impact of trade liberalization on growth. The results are presented in table 3 .

The model is a dynamic panel model because some of the growth determinant variables are endogenous (predetermined) and current period growth is assumed to be influenced by its lagged.

GDP (-1) is the initial GDP growth rate of each of the five countries used in the model. The inclusion of this variable allows us to consider the initial endowment of each country, with the aim of computing the convergence phenomenon between the economies (Barro and Sala Martin, 1996). There was prior expectation of a positive relationship between GDPIt-1 on the 
current level rate of growth.

The coefficient of initial growth is positive and highly significant in explaining economic growth. This is in line with our prior expectation of a positive relationship between the two variables. We find that a 1 percent increase in growth rate from a previous year leads to a 39 percent rise in economic growth in the current period. This further indicates a case of non-convergence, thus the countries with higher initial income experience higher growth than those with lower initial income levels.

The coefficient of liberalization proxy is also positive and marginally significant. Under both the static and dynamic model trade liberalization has been found to exert positive impact on economic growth rate. The different in results between the two estimates lies only in the magnitude of influence and the degree of significance.

The rest of the variables are all statistically significant except exchange rate and human capital formation having $\mathrm{p}$ values of 0.121 and 0.806 . In sum, in a dynamic setting, economic growth is mainly driven by previous years' growth, trade openness, foreign direct investment and gross capital formation.

Table 3. Dependent Variable: GDP growth rate

\begin{tabular}{|l|l|l|l|l|}
\hline Variable & Coefficient & Std error & $\mathrm{Z}$ & $\mathrm{p}>\mathrm{z}$ \\
\hline Gdp $(-1)$ & 0.3929663 & 0.0889937 & 4.43 & 0.000 \\
\hline To & 2.912161 & 1.726688 & 1.69 & 0.092 \\
\hline lnfdi & 1.171493 & 0.3400205 & 3.45 & 0.001 \\
\hline lngfcf & 2578615 & 0.127867 & 2.02 & 0.044 \\
\hline Lnexrate & -2.917356 & 1.879298 & -1.55 & 0.121 \\
\hline Lnpopulation & -12.88076 & 6.911508 & -1.86 & 0.062 \\
\hline Lnhcf & $4683212 \quad 1.903442$ & 1.903442 & 0.25 & 0.806 \\
\hline
\end{tabular}

Note lag (1) of the variables were used as their instruments

\subsubsection{Policy Suggestions}

The study has confirmed the positive impact of integrating an economy into the global economic system. The results have important policy implication.

It is suggested that developing countries that want to follow the path of BRICS economies to economic recognition should consider developing internal institutions that leads to a greater trade openness (liberalization). In addition, for BRICS countries to become world super power nations by year 2050 as envisioned international trade would play a very important role. Hence there is the need to consolidate the gains from trade whiles dealing with challenges such as financial crisis

Political crisis etc that have potential of inhibiting trade potentials.

Is also recommended that the developing countries should properly manage their exchange rates; an exchange rate that does not erode their competitiveness on the world market, but rather, promotes exports and hence production and growth as practiced by the BRICS in 
recent years.

Developing countries should also invest a lot on human capital formation. It refers to the intellectual ability of the labour force. It determines the quality of the labour force. If it is developed, then the labour force will have a higher productivity so that economic growth will be accelerated. Therefore, it is important for the government to invest in education. This is the only way to develop the mental ability and the potential of the population. So the more the labour force is trained, qualified, skilled and adaptable to changes in technology, the higher will be the productivity and hence economic growth. Education should be directed in such a way as to develop the managerial as well as the entrepreneurial ability of the population as done in the BRICS countries in recent years. Investment in education will also ensure that the growing population becomes an asset rather than a burden as in the case of BRICS as their large population sizes has been a dividend contributing to their higher growth performance.

\subsubsection{Conclusion, Limitations and Suggestions for Further Studies}

The current study fills the gap in literature by analyzing the nexus between trade liberalization and economic growth in the BRICS economies. Both static and dynamic panel data models were estimated. The static model uses fixed effect model while the Arellano-Bond approach to GMM was used for the dynamic estimation.

GDP per capita growth rate, trade openness, gross fixed capital formation, human capital formation, exchange rate and population size of individual countries were the variables used in the estimation. GDP growth rate was the dependent variable whiles the remaining variables were used as explanatory variables with the principal explanatory variable of interest being trade openness. From the results of the study it is concluded that Trade openness has positive and significant impact on economic growth.

It is therefore recommended that a developing country that wants to follow the pace of economic development of BRICS countries that they initiate institutional and structural reforms that would enable them compete favorably in international trade.

As no knowledge is ever exhaustive or free from limitation, so is this study. the study covers sample period of 1990 to 2014 however we believe that a longer sample period would have given a more robust results than the one chosen.

The study also included only BRICS countries (Brazil, Russian federation, India, china, and South Africa). Research has shown that these countries liberalized the economies only when they have developed a strong institution that could withstand international competition emanating from trade liberalization. A note of caution to other developing countries is therefore in order. Unless there exist strong and efficient internal structures and institutions that can compete favorably in the international market, liberalization policy should be taken with care.

The use of trade openness as a proxy for trade liberalization though extensively used in research may also be misleading as it fails to differentiate export role from import. 


\section{Al Macrothink}

Business and Economic Research ISSN 2162-4860 2016, Vol. 6, No. 2

Liberalizing trade may affect countries terms of trade when it leads to more import than exports and this may further affect local industries and economic growth. It is therefore recommended for further studies to look for other varies that truly measures trade liberalization. Tariff rate or a liberalization index constructed using principal component analysis may be helpful.

\section{References}

Adam, Smith, (1776). An Inquiry into the nature and causes of the Wealth of Nations', 5th edition. London, Methuen and Co Ltd, ed. Edwin Cannan, 1904, Bloomberg. 2010. Accessed fromhttp://www.bloomberg.com/news/2010-12-24/south-africa-asked-to-join-bric-to-boost-c ooperation-with-emerging-markets.html

Anwer, M. S., \& Sampath, R. K., (2001). Exports and Economics Growth, Indian Economic Journal, 47(3), 79-88

Arellano, M., \& Bond, S. (1991). Some tests of specification for panel data: Monte Carlo evidence and an application to employment equations. Review of Economic Studies, 58, 277-297. https://doi.org/10.2307/2297968

Baldwin, Richard, E. (1992). Measurable dynamic gains from trade, Journal of Political Economy, 100(1), 162-74. https://doi.org/10.1086/261811

Bhattacharya, M., \& Bhattacharya, S. N. (2011): The Interrelationship between Merchandise Trade, Economic Growth and FDI Inflows in India, South-Eastern Europe Journal of Economics, 2, 229-244

Chow, P. C. Y., (1987). Causality between export growth and industrial development: empirical evidence from the NICs. Journal of Development Economics, 26, 55-63. https://doi.org/10.1016/0304-3878(87)90051-4

Daumal, M., \& Ozyurt, S. (2010). The Impact of International Trade Flows on The Growth of Brazilian States, University of Paris Working Paper DT/2010-01

Dutt, S. D., \& Ghosh, D. (1996). The export Growth-Economic growth nexus: A causality analysis. Journal of Developing Areas, 30, 167-82.

Fan, Z., Z., \& Verbiest, J. P. (2005). Growth and Trade Horizons for Asia: Long-term Forecasts for Regional Integration, Asian Development Review, 22(2), 32.

Feder, G. (1982). On export and economic growth. Journal of Development Economics, 12, 59-73. https://doi.org/10.1016/0304-3878(83)90031-7

Ghartey, E. E. (1993). Causal Relationship between Exports and Economic Growth: Some Empirical Evidence in Taiwan, Japan and the US, Applied-Economics, (9), 1145-1152. https://doi.org/10.1080/00036849300000175

Grossman, G., \& Helpman, E. (1992). Innovation and Growth in the Global Economy, Cambridge: MIT Press, 1991, chapters 1-5. 


\section{I Macrothink}

Business and Economic Research ISSN 2162-4860 2016, Vol. 6, No. 2

Heckscher, Eli. (1919). The Effects of Foreign Trade on the Distribution of Income, Ekonomisk Tidskrift, 21, 497-512.

Helpman, E. (1981). International trade in the presence of product differentiation, economies of scale, and monopolistic competition: A Chamberlin-Heckscher-Ohlin approach, Journal of International Economics, 11, 305-340. https://doi.org/10.1016/0022-1996(81)90001-5

Hondroyiannis, P. A. V. B. S., George, S. Tavlas, \& Michael, Ulan. (2005). Some Further Evidence on Exchange-Rate Volatility and Exports, Working Papers 28, Bank of Greece

International Centre for Trade and Sustainable Development. 2012. A glance at Africa's engagement with the BRICS. Accessed from http://ictsd.org/i/news/bridges-africa-review/134367/

Kowalski, P., Lattimore, R., \& Bottini, N. (2009). South Africa's Trade and Growth, OECD Trade Policy Working Papers, No. 91, OECD Publishing.

Krugman, P. R. (1979). A Model of Innovation, Technology Transfer, and the World Distribution of Income, Journal of Political Economy, 87(2), 253-66.

https://doi.org/10.1086/260755

Krugman, P. R. (1979). Increasing returns, monopolistic competition, and international trade, Journal of International Economics, 9(4), 469-479.

https://doi.org/10.1016/0022-1996(79)90017-5

Kwan, J. A., \& Cotsomitis, C. C. (1991) Economic Growth and the Expanding Export Sector: China 1952-1985, International Economic Journal, 5(1), 105-116.

https://doi.org/10.1080/10168739100000008

Lancaster, Kelvin, (1980), Intra-industry trade under perfect monopolistic competition, Journal of International Economics, 10, 151-175.

https://doi.org/10.1016/0022-1996(80)90052-5

Ledyaeva, S., \& Linden, M. (2008). Determinants of Economic Growth: Empirical Evidence from Russian Regions the European. Journal of Comparative Economics, 5(1), 87-105

Lee, J. W. (1993). International trade, distortion and long-run economic growth, International Mnetary Fund Staff paper, 40(2), 299-328.

Lee, J. W. (1993). International trade, distortion and long-run economic growth, International Monetary Fund Staff paper, 40(2), 299-328.

Li, J. (1996). Energy Economics in Building Modern China. In Energizing China: Reconciling Environmental Protection and Economic Growth, eds. Michael B. McElroy, Chris P. Nielsen, and Peter Lydon. Cambridge, MA: Harvard University Press, 1997.

Loots, E. (2002). Globalization and Economic Growth in South Africa: Do We Benefit from Trade and Financial Liberalisation?, RAU Research Paper No. 0206, November, RAU Department of Economics 


\section{Macrothink}

Business and Economic Research ISSN 2162-4860 2016, Vol. 6, No. 2

Lucas, R (1988). On the Mechanics of Economic Development, Journal of Monetary Economics, 22(1), 3-42.

Mail \& Guardian (2013). Online. Accessed from http://mg.co.za/ article/2013-03-28-00

Mankiw, N. G., Romer, D., \& Weil. D. N. (1992). A Contribution to the Empirics of Economic Growth, The Quarterly Journal of Economics, 107(2), 407-37.

https://doi.org/10.2307/2118477

Martínez, Z., \& Ramos, M. (2005). International Trade, Technological Innovation and Income: A Gravity Model Approach, Working Papers. Serie EC 2005-15, Institution Valenciano de Investigations Economics, S.A. (Ivie)

Matos, O. C. (2003). Interrelationships between Financial Development, Trade and Growth Economy: Analysis of the Brazilian Experience. Technical Notes of the Central Bank of Brazil, No. 40, October 2003.

Nidugala, G. K. (2001). Export and Economic Growth in India: An Empirical Investigation, Indian Economic Journal, 47(3), 67-78

Ohlin, Bertil, (1933). Inter-regional and International Trade, Harvard University Press, Cambridge, 1933.

Ricardo, D. (1817). On the Principles of Political Economy and Taxation (1817)'- 3rd edition by Batoche Brooks Kitchener 2001

Romer, P. M, (1994). The Origins of Endogenous Growth, Journal of Economic Perspectives, American Economic Association, 8(1), 3-22.

Romer, P. M. (1986). Increasing Returns and Long Run Growth, Journal of Political Economy, 94, 1002-37. https://doi.org/10.1086/261420

Shan, J., \& Sun, F. (1998). Export-led Growth Hypothesis for Australia: An Empirical Reinvestigation. Applied Economics Letters, 5, 423-428.

https://doi.org/10.1080/135048598354555

Shan, J., \& Sun, F. (1998). On The Export-led Growth Hypothesis: The Econometric Evidence from China. Applied Economics, (30). https://doi.org/10.1080/000368498325228

Shan, J., \& Sun, F. (1998). On the Export-led Growth Hypothesis: The econometric Evidence from China. Applied Economics, 30, 1055-1065. https://doi.org/10.1080/000368498325228

Tong J. (1995), Growth and causality in China, Journal of Development Economics, (18), $1-12$

Trading Economics. (2013). Accessed from http://www.tradingeconomics.com/china/exports

United Nations Development Programme. Human Development Report (2011). Accessed from http://hdr.undp.org/en/media/HDR_2011_EN_Chapter2.pdf

Wilson, D., \& Purushothaman, R. (2003). Dreaming with BRICs: The path to 2050. Global 
economics paper no. 99.

\section{Copyright Disclaimer}

Copyright for this article is retained by the author(s), with first publication rights granted to the journal.

This is an open-access article distributed under the terms and conditions of the Creative Commons Attribution license (http://creativecommons.org/licenses/by/3.0/). 